\title{
To Estimate Trace Elements, Oxidative Stress and Antioxidant during Preeclampsia and Eclampsia
}

\author{
Sonali Rajdev ${ }^{1}$, Dr. B.K. Agarwal2 ${ }^{2 *}$, Dr. Shreya Nigoskar ${ }^{3}$ \\ ${ }^{1} \mathrm{PhD}$ research Scholar Department of Biochemistry, Index Medical College, Malwanchal University, Index City, NH-59A, Nemawar Rd, Indore, \\ Madhya Pradesh 452016, India \\ ${ }^{2}$ Professor, Department of Biochemistry, Index Medical College, Malwanchal University, Index City, NH-59A, Nemawar Rd, Indore, Madhya Pradesh \\ 452016, India \\ ${ }^{3}$ Professor and Head, Department of Biochemistry, Index Medical College, Malwanchal University, Index City, NH-59A, Nemawar Rd, Indore, \\ Madhya Pradesh 452016, India
}

DOI: $10.36348 /$ sijb.2020.v03i12.003 $\quad$ | Received: 03.12.2020 | Accepted: 16.12.2020 | Published: 20.12 .2020

*Corresponding author: Dr. B.K. Agarwal

\section{Abstract}

Introduction: Pregnancy is characterized by significant metabolic and hemodynamic changes that begin early in the gestational period. Major hemodynamic changes include an increase in the cardiac output during the first trimester, sodium and water retention leading to plasma volume expansion with a peak around week 30 , and reductions in the systemic vascular resistance and systemic blood pressure. Material and Methods: This is prospective and observational study conducted at Department of Biochemistry in association of Department of General Medicine. In this study investigation was done to determine the contribution of different biochemical parameters of females suffering from preeclampsia and Eclampsia. Results: Serum iron level in case group $18.43 \pm 8.49 \mu \mathrm{mol} / \mathrm{L}$ and control group $15.92 \pm$ 8.23. Moreover, Serum Zinc level $8.4 \pm 1.9 \mu \mathrm{mol} / \mathrm{L}$ and control group $9.3 \pm 1.2 \mu \mathrm{mol} / \mathrm{L}$. Furthermore, Serum Copper level $17.3 \pm 5.3 \mu \mathrm{mol} / \mathrm{L}$ and control group $9.6 \pm 1.9 \mu \mathrm{mol} / \mathrm{L}$. Oxidative marker between Case and control group was statistically significantly difference. MDA in case group was $3.18 \pm 0.43 \mathrm{nM} / \mathrm{mL}$ and Control $1.63 \pm 0.32 \mathrm{nM} / \mathrm{mL}$. Antioxidant marker between Case and control group was statistically significantly difference. In case group Glutathione peroxidase $9.53 \pm 2.46 \mu \mathrm{mol} / \mathrm{ml}$ and control group $11.68 \pm 3.63 \mu \mathrm{mol} / \mathrm{ml}$. Conclusion: The results obtained support our initial hypothesis that common differences between all pregnant women and controls could be revealed, while preeclampsia and the other pregnancies would further differ indicating specific misbalance of the oxidative stress in preeclampsia.

Keywords: Preeclampsia, Eclampsia, Oxidative stress, Antioxidant during.

Copyright (C) 2020 The Author(s): This is an open-access article distributed under the terms of the Creative Commons Attribution 4.0 International License (CC BY-NC 4.0) which permits unrestricted use, distribution, and reproduction in any medium for non-commercial use provided the original author and source are credited.

\section{INTRODUCTION}

Pregnancy is characterized by significant metabolic and hemodynamic changes that begin early in the gestational period. Major hemodynamic changes include an increase in the cardiac output during the first trimester, sodium and water retention leading to plasma volume expansion with a peak around week 30, and reductions in the systemic vascular resistance and systemic blood pressure [1]. The reduction of the systemic vascular resistance is around $25 \%$ and is due to the increase in vasodilating agents, like nitric oxide and prostacyclin production, and the decrease in the sensitivity to norepinephrine and angiotensin [2]. The diastolic blood pressure begins to decrease from the 7 th week of gestation, with a $10-\mathrm{mmHg}$ decline between the 24th-26th gestation weeks, returning to normal values during the third trimester [3].
These are some of the changes that can occur during pregnancy. Hypertension is the most prevalent maternal complication worldwide (several studies estimate that it affects $7-10 \%$ of all pregnancies), and it is associated with a significant morbidity and mortality of the mother and fetus [4]. In fact, hypertension is the second largest cause of direct maternal death worldwide ( $14 \%$ of the total), and it is estimated that 192 people die every day because of hypertensive disorders in pregnancy [5].

Pre-eclampsia and eclampsia are two hypertensive disorders of pregnancy, considered as major causes of maternal and perinatal morbidity and mortality [6]. These diseases affect between $3 \%$ and $5 \%$ of all pregnancies and account for more than 60,000 maternal and 500,000 fetal deaths per year worldwide [7]. It is known that pre-eclampsia and eclampsia are 
the hypertensive disorders that involve the most significant health risks for the pregnant woman and the fetus. In this context, it is imperative to evaluate whether all possible and necessary measures are being taken correctly in terms of prevention, maintenance, and treatment of the disease [8].

\section{MATERIAL AND METHODS}

In this study investigation was done to determine the contribution of different biochemical parameters of females suffering from preeclampsia and Eclampsia.

The present study was carried out in the Department of Biochemistry in association of Department of General Medicine.

Biochemical parameters included: Iron, Zinc, Copper, Malondialdehyde (MDA), Glutathione.

The study was carried out on Case group - 100 pre-eclampsia and eclampsia patients compare to Control group - 100 normal pregnant females.

\section{Selection Criteria}

1. Control: Normal pregnant females randomly selected from the hospital who is not suffering from any other medical disorder.

2. Cases: All the patients of preeclampsia and Eclampsia will be admitted in the hospital.

Inclusion Criteria: Pregnant female suffering from preeclampsia and eclampsia.

Exclusion Criteria: Pregnant females suffering from any other medical disorder.

\section{RESULTS \\ Physical Parameters}

In Table-1, the mean age of the case and control pregnant women was 29.3 years and 31.2 years respectively which was statistically not significantly different from those of control group $(\mathrm{P}>0.05)$. Whereas, BMI between case and control group $26.4 \pm$ $3.8 \mathrm{~kg} / \mathrm{m}^{2}$ versus $25.7 \pm 3.0 \mathrm{~kg} / \mathrm{m}^{2}$ respectively which was statistically not significantly different from those of control group $(\mathrm{P}>0.05)$.

Table-1: Distribution of Anthropometric parameters between Case and control group

\begin{tabular}{|l|l|l|l|l|}
\hline Parameters & Age in years & BMI $\left(\mathbf{k g} / \mathbf{m}^{2}\right)$ & SBP $(\mathbf{m m H g})$ & DBP $(\mathbf{m m H g})$ \\
\hline Case $($ mean \pm SD) & 28.4 & $26.3 \pm 2.9$ & $167.24 \pm 12.3$ & $99.54 \pm 7.2$ \\
\hline Control $($ mean \pm SD) & 30.2 & $25.8 \pm 3.1$ & $127.18 \pm 10.6$ & $79.32 \pm 6.9$ \\
\hline t-value & 1.64 & 1.32 & 29.31 & 17.01 \\
\hline p-value & $\mathrm{p}=0.94$ & $\mathrm{p}=0.81$ & $\mathrm{p}=0.02$ & $\mathrm{p}<0.001$ \\
\hline
\end{tabular}

$\mathrm{SD}=$ Standard deviation; $\mathrm{Kg} / \mathrm{m}^{2}=$ kilogram per meter square; $\mathrm{N}=$ total number of patients; $\mathrm{BMI}=$ body mass index;

$\mathrm{SBP}=$ systolic blood pressure; $\mathrm{DBP}=$ diastolic blood pressure; $\mathrm{mmHg}=$ millimetre mercury; $\mathrm{N}=100$.

In Table-1, there was a significant difference $(\mathrm{P}<0.05)$ between both the systolic and diastolic blood pressures of the case and control groups. The systolic blood pressure in case group was $167.24 \pm 12.3 \mathrm{mmHg}$ and control group $127.18 \pm 10.6 \mathrm{mmHg}$. On the other hand, diastolic blood pressure in case group was 99.54 $\pm 7.2 \mathrm{mmHg}$ and control group $79.32 \pm 6.9 \mathrm{mmHg}$.

Table-2: Distribution of Biochemical parameters between Case and control group

\begin{tabular}{|l|l|l|l|}
\hline Parameters & Fe $(\boldsymbol{\mu m o l} / \mathbf{L})$ & Zinc $(\boldsymbol{\mu m o l} / \mathbf{L})$ & Copper $(\boldsymbol{\mu m o l} / \mathbf{L})$ \\
\hline Case $($ mean $\pm \mathrm{SD})$ & $18.43 \pm 8.49$ & $8.4 \pm 1.9$ & $17.3 \pm 5.3$ \\
\hline Control $($ mean $\pm \mathrm{SD})$ & $15.92 \pm 8.23$ & $9.3 \pm 1.2$ & $9.6 \pm 1.9$ \\
\hline t-value & 13.7 & 3.2 & 14.73 \\
\hline $\mathrm{p}$-value & $\mathrm{p}<0.001$ & $\mathrm{p}=0.06$ & $\mathrm{p}<0.001$ \\
\hline
\end{tabular} Standard deviation; $\mu \mathrm{mol} /=$ millimole per litre; $\mathrm{N}=$ total number of patients; $\mathrm{N}=100$.

\section{Biochemical Parameters}

The mean serum concentrations of zinc, copper, and iron statistically significantly difference $(\mathrm{P}$ $<0.05)$ in pre-eclampsia and eclampsia patients in comparison to the control group (Table 2 and Graph 2).
Serum iron level in case group $18.43 \pm 8.49 \mu \mathrm{mol} / \mathrm{L}$ and control group $15.92 \pm 8.23$. Moreover, Serum Zinc level $8.4 \pm 1.9 \mu \mathrm{mol} / \mathrm{L}$ and control group $9.3 \pm 1.2$ $\mu \mathrm{mol} / \mathrm{L}$. Furthermore, Serum Copper level $17.3 \pm 5.3$ $\mu \mathrm{mol} / \mathrm{L}$ and control group $9.6 \pm 1.9 \mu \mathrm{mol} / \mathrm{L}$.

Table-3: Distribution of Oxidative marker between Case and control group

\begin{tabular}{|l|l|}
\hline Parameters & Malondialdehyde $(\mathbf{n M} / \mathbf{m L})$ \\
\hline Case $($ mean \pm SD) & $3.18 \pm 0.43$ \\
\hline Control $($ mean \pm SD) & $1.63 \pm 0.32$ \\
\hline t-value & 14.29 \\
\hline p-value & $\mathrm{p}<0.001$ \\
\hline
\end{tabular}

$\mathrm{SD}=$ Standard deviation; $\mathrm{N}=$ total number of patients; $\mathrm{N}=100$. 
In Table-3 and Graph-3, Oxidative marker between Case and control group was statistically significantly difference. MDA in case group was $3.18 \pm$ $0.43 \mathrm{nM} / \mathrm{mL}$ and Control $1.63 \pm 0.32 \mathrm{nM} / \mathrm{mL}$.

Table-4: Antioxidant marker between Case and control group

\begin{tabular}{|l|l|}
\hline Parameters & Glutathione peroxidase $(\boldsymbol{\mu m o l} / \mathbf{m l})$ \\
\hline Case $($ mean $\pm \mathrm{SD})$ & $9.48 \pm 1.59$ \\
\hline Control $($ mean $\pm \mathrm{SD})$ & $12.95 \pm 3.75$ \\
\hline t-value & 16.38 \\
\hline p-value & $\mathrm{p}<0.001$ \\
\hline
\end{tabular}

$\mathrm{SD}=$ Standard deviation; $\mu \mathrm{mol} /=$ millimole per litre $; \mathrm{N}=$ total number of patients; $\mathrm{N}=100$.

In Table-4, Antioxidant marker between Case and control group was statistically significantly difference. In case group Glutathione peroxidase $9.53 \pm$ $2.46 \mu \mathrm{mol} / \mathrm{ml}$ and control group $11.68 \pm 3.63 \mu \mathrm{mol} / \mathrm{ml}$.

Table-5: Antioxidant marker between Case and control group

\begin{tabular}{|l|l|l|l|}
\hline Parameters & Vitamin C $(\mathbf{m g} / \mathbf{d l})$ & Vitamin E $(\mathbf{m g} / \mathbf{L})$ & Uric acid $(\mathbf{m g} / \mathbf{d l})$ \\
\hline Case $($ mean $\pm \mathrm{SD})$ & $0.63 \pm 0.12$ & $7.63 \pm 1.48$ & $7.54 \pm 1.64$ \\
\hline Control $($ mean \pm SD) & $1.37 \pm 0.15$ & $12.49 \pm 2.53$ & $4.43 \pm 0.41$ \\
\hline t-value & 7.53 & 12.54 & 15.59 \\
\hline p-value & $\mathrm{p}<0.001$ & $\mathrm{p}<0.001$ & $\mathrm{p}<0.001$ \\
\hline
\end{tabular}

$\mathrm{SD}=$ Standard deviation; $\mu \mathrm{mol} /=$ millimole per litre; $\mathrm{N}=$ total number of patients; $\mathrm{N}=100$.

In Table-5, Antioxidant marker between Case and control group was statistically significantly difference. In case group Vitamin $\mathrm{C}$ was $0.63 \pm 0.12$ $\mathrm{mg} / \mathrm{dl}$ and control group $1.37 \pm 0.15 \mathrm{mg} / \mathrm{dl} / \mathrm{ml}$. In case group Vitamin $\mathrm{E}$ was $7.63 \pm 1.48 \mathrm{mg} / \mathrm{L}$ and control group $12.49 \pm 2.53 \mathrm{mg} / \mathrm{dl} / \mathrm{L}$. In case group of Uric acid was $7.54 \pm 1.64 \mathrm{mg} / \mathrm{dl}$ and control group $4.43 \pm$ $0.41 \mathrm{mg} / \mathrm{dl} / \mathrm{ml}$.

\section{DISCUSSION}

Preeclampsia, which affects $2-7 \%$ of all pregnancies, is a syndrome that is associated with multiorgan dysfunction and is characterized by newonset hypertension (blood pressure >140/90 mm Hg) and proteinuria (>300 mg/24 h) after $20 \mathrm{wk}$ of gestation [9]. The precise mechanisms that lead to preeclampsia, which often occurs without warning and may follow a precipitous course, are not known; however, failure of the normal processes of placentation followed by inadequate placental perfusion would seem to be a necessary prelude to the cascade of molecular events that culminate in the maternal syndrome [10]. Numerous studies have described elevated markers of oxidative stress in placental tissue from women with preeclampsia [11].

Pregnancy increases oxidative stress, a condition that can be aggravated with preeclampsia, because free radicals are detrimental to the integrity of the endothelium, causing maternal vascular dysfunction [12]. According to this knowledge, preeclampsia is a condition where there is an imbalance between the endogenous antioxidant system and free radicals, mostly ROS. These species are caused by: mitochondrial aerobic metabolism, activation of NADPH oxidase, xanthine oxidase (XO), cytochrome P450 and lipid peroxidation process (CAT), glutathione peroxidase (GPx) and glutathione reductase (GR)) and nonenzymatic (vitamin E, C, carotene, glutathione) [13]. Under physiological conditions, these defense mechanisms maintain a low concentration of ROS in the cell and its activity is regulated, hence the balance between ROS production and antioxidant defenses determines the degree of oxidative stress [14].

MDA is constantly being generated in body fluids though various mechanisms and is continually removed by the endogenous antioxidant defense system. In addition to the technical points, MDA levels change with the circadian rhythm, which is another shortcoming in its role as an acceptable biomarker [15]. To further support our hypothesis, we compared the MDA levels of healthy non-pregnant group from some available studies from a given university, i.e., Kahramanmaras Sutcu Imam University. Serum MDA levels of $8.7 \mathrm{nmol} / \mathrm{mL}, 2.20 \pm 0.28 \mathrm{nmol} / \mathrm{mL}, 4.4 \pm 0.5$ $\mathrm{nmol} / \mathrm{mL}$ were found from various study [16-18]. It should be noted that the two latter works employed slightly different analytical conditions. Interestingly, the results reported in reference are a thousand times higher than the values in other reports [19].

Several antioxidant markers have been shown to be significantly decreased in preeclamptic women [20]. In the maternal circulation, the levels of enzymatic as well as nonenzymatic antioxidant markers, such as vitamins $\mathrm{C}, \mathrm{E}$, glutathione, iron, zinc, and copper may 
be altered [21]. Studies have also shown that women with preeclampsia have significantly reduced serum coenzyme Q10 [22] as well as serum and/or placental carotene, lycopene, and canthaxanthin [23]. One study focused on the evaluation of the total antioxidant response (TAR) determined by the redox status of the plasma, as well as the oxidative stress index (OSI), calculated from the percent ratio of the total plasma peroxide levels in preeclamptic women [24]. Both parameters were found to be significantly higher in patients with preeclampsia. A twofold increase in the ratio between LPO and antioxidant capacity was observed in the antepartum period in women with preeclampsia [25]. At the same time, Hilari et al. found that women whose pregnancies were complicated by mild preeclampsia had increased levels of total oxidant status (TOS) and a decreased total antioxidant status (TAS) level compared to women with normal pregnancies [26].

Glutathione is another antioxidant to be found modified in a preeclamptic placenta [27]. Furthermore, Rosta et al. [28] suggested the role of SOD3 single nucleotide gene polymorphisms in the increased oxidative stress in preeclampsia. Significantly lower levels of ascorbic acid were reported in the plasma of women with mild to severe preeclampsia [29]. Similarly, serum alpha-tocopherol levels were significantly reduced in pregnancies complicated by severe preeclampsia. As LPO is commonly observed in preeclamptic patients, the balance between lipid peroxides and antioxidant vitamin $\mathrm{E}$ will be tipped in favor of lipid peroxides in patients with mild and severe preeclampsia. In a controlled clinical trial, significantly lower levels of vitamin C, E, and total thiols were seen in women with preeclampsia [30]. Furthermore, significantly reduced whole blood glutathione levels have been reported in women with preeclampsia and HELPP syndrome [31].

\section{CONCLUSION}

Our study has noticed that the role of oxidative stress and antioxidant capacity in preeclampsia and Eclampsia. By assessing markers of lipid peroxidation and antioxidant capacity, we achieved unequivocal evidence for oxidative stress in this disorder. In the light of the above interpretations it can be determined that pre-eclamptic pregnant women have higher levels of MDA while decreased level of reduced glutathione and the difference were very highly significant. Our finding on role of antioxidant in preeclampsia normal pregnant women the result showed beneficial affect with the significant differences. It may provide new insight into a potentially modifiable way to prevent preeclampsia when the vitamins are administrated in diets.

\section{REFERENCES}

1. Gongora, M. C., \& Wenger, N. K. (2015). Cardiovascular complications of pregnancy. International journal of molecular sciences, 16(10), 23905-23928.

2. Flack, J. M., Peters, R., Mehra, V. C., \& Nasser, S. A. (2002). Hypertension in special populations. Cardiology clinics, 20(2), 303-19.

3. Mustafa, R., Ahmed, S., Gupta, A., \& Venuto, R. C. (2012). A comprehensive review of hypertension in pregnancy. Journal of pregnancy, 2012:105918.

4. Ahmad, A. S., \& Samuelsen, S. O. (2012). Hypertensive disorders in pregnancy and fetal death at different gestational lengths: a population study of 2121371 pregnancies. BJOG: An International Journal of Obstetrics \& Gynaecology, 119(12), 1521-1528.

5. Lindheimer, M. D., Taler, S. J., \& Cunningham, F. G. (2010). Hypertension in pregnancy. J Am Soc Hypertens. 4, 68-78.

6. Inversetti, A., Smid, M., Candiani, M., Ferrari, M., \& Galbiati, S. (2014). Predictive biomarkers of pre-eclampsia and effectiveness of preventative interventions for the disease. Expert opinion on biological therapy, 14(8), 1161-1173.

7. Montenegro, N., Campos, D. A., Rodrigues, T., Ramalho, C., Silva, J. L., \& Machado, A. P. (2014). Pré-eclâmpsia: Vigilância e tratamento. In Protocolos de Medicina Materno-Fetal, 3rd ed. LIDEL, Ed.; LIDEL: Lisboa, Portugal. 122-129.

8. Júlio, C., Francisco, C., Dias, E., \& Campos, A. (2011). Pré-eclâmpsia. In Protocolos de Atuação da Maternidade dr. Alfredo da Costa, 2nd ed.; LIDEL, Ed.; LIDEL: Lisboa, Portugal, 39-48.

9. Podymow, T., \& August, P. (2011, January). Antihypertensive drugs in pregnancy. In Seminars in nephrology (Vol. 31, No. 1, pp. 70-85). WB Saunders.

10. Bouet, P. E., Brun, S., Madar, H., Baisson, A. L., Courtay, V., Gascoin-Lachambre, G., ... \& Sentilhes, L. (2015). Implementation of an antenatal magnesium sulfate protocol for fetal neuroprotection in preterm infants. Scientific reports, 5(1), 1-8.

11. Paré, E., Parry, S., McElrath, T. F., Pucci, D., Newton, A., \& Lim, K. H. (2014). Clinical risk factors for preeclampsia in the 21st century. Obstetrics \& Gynecology, 124(4), 763770 .

12. Spradley, F. T. (2017). Metabolic abnormalities and obesity's impact on the risk for developing preeclampsia. American Journal of PhysiologyRegulatory, Integrative and Comparative Physiology, 312(1), R5-R12.

13. Roberge, S., Villa, P., Nicolaides, K., Giguère, Y., Vainio, M., Bakthi, A., ... \& Bujold, E. (2012). Early administration of low-dose aspirin for the prevention of preterm and term preeclampsia: a 
systematic review and meta-analysis. Fetal diagnosis and therapy, 31(3), 141-146.

14. Bowen, R. S., Moodley, J., Dutton, M. F., \& Theron, A. J. (2001). Oxidative stress in preeclampsia. Acta obstetricia et gynecologica Scandinavica, 80(8), 719-725.

15. Serdar, Z., Gür, E., Çolakoðullarý, M., Develioðlu, O., \& Sarandöl, E. (2003). Lipid and protein oxidation and antioxidant function in women with mild and severe preeclampsia. Archives of gynecology and obstetrics, 268(1), 19-25.

16. Mikhail, M. S., Anyaegbunam, A., Garfinkel, D., Palan, P. R., Basu, J., \& Romney, S. L. (1994). Preeclampsia and antioxidant nutrients: decreased plasma levels of reduced ascorbic acid, $\alpha$ tocopherol, and beta-carotene in women with preeclampsia. American journal of obstetrics and gynecology, 171(1), 150-157.

17. Ziari, S. A., Mireles, V. L., Cantu, C. G., Cervantes, M., Idrisa, A., Bobsom, D., ... \& Glew, R. H. (1996). Serum vitamin A, vitamin E, and beta-carotene levels in preeclamptic women in northern Nigeria. American journal of perinatology, 13(05), 287-291.

18. Gupta, S., Aziz, N., Sekhon, L., Agarwal, R., Mansour, G., Li, J., \& Agarwal, A. (2009). Lipid peroxidation and antioxidant status in preeclampsia: a systematic review. Obstetrical \& gynecological survey, 64(11), 750-759.

19. Chappell, L. C., Seed, P. T., Briley, A., Kelly, F. J., Hunt, B. J., Charnock-Jones, D. S., ... \& Poston, L. (2002). A longitudinal study of biochemical variables in women at risk of preeclampsia. American journal of obstetrics and gynecology, 187(1), 127-136.

20. Chappell, L. C., Seed, P. T., Briley, A. L., Kelly, F. J., Lee, R., Hunt, B. J., ... \& Poston, L. (1999). Effect of antioxidants on the occurrence of preeclampsia in women at increased risk: a randomised trial. The Lancet, 354(9181), 810-816.

21. Roes, E. M., Raijmakers, M. T., Hendriks, J. C., Langeslag, M., Peters, W. H., \& Steegers, E. A. (2005). Maternal antioxidant concentrations after uncomplicated pregnancies. Free radical research, 39(1), 95-103.

22. Talwar, D., Ha, T. K., Cooney, J., Brownlee, C., \& St JO'Reilly, D. (1998). A routine method for the simultaneous measurement of retinol, $\alpha$ tocopherol and five carotenoids in human plasma by reverse phase HPLC. Clinica Chimica Acta, 270(2), 85-100.

23. Howlader, Z. H., Kabir, Y., Khan, T. A., Islam, R., Begum, F., \& Huffman, F. G. (2007). Plasma lipid profile, lipid peroxidation and antioxidant status in preeclamptic and uncomplicated pregnancies in Bangladesh. J Med Sci, 7(8), 127682.

24. Kaur, G., Mishra, S., Sehgal, A., \& Prasad, R. (2008). Alterations in lipid peroxidation and antioxidant status in pregnancy with preeclampsia. Molecular and cellular biochemistry, 313(1-2), 37-44.

25. Akarsu E, Buyukhatipoglut H, Aktaran S, et al. Effects of pulse methylprednisolone and oral methylprednisone treatments on serum levels of oxidative stress markers in Graves' ophthalmophathy. Clin Endocrinol. 2011;74:118124.

26. Gokirmak M, Yildirim Z, Hasanoglu HC, et al. The role of oxidative stress in bronchoconstriction due to occupational sulfur dioxide exposure. Clin Chim Acta. 2003;331:119-126.

27. Khoubnasabjafar M, Ansarin K, Jouyban A. Critical review of malondialdehyde analysis in biological samples. Cur Pharm Anal. 2015;16:4-

28. Koroglu S, Tuncer C, Acar G, et al. Realation of inflammatory and oxidative markers to the occurrence and recurrence of persistent atrial fibrillation. Arch Turk Soc Cardiol. 2012;40:499_ 504.

29. Ozturk P, Kurtas E, Ataseven A. Copper/zinc and copper/selenium ratios, and oxidative stress as biochemical markers in recurrent aphthous stomatitis. J Trace Element Med Biol. 2013;24:312-316.

30. Sarandol E, Dirican M, Serdar Z. Oxidizability of apolipoprotein B-containing lipoproteins, levels of lipid peroxidation products and antioxidants in normal pregnancy. Arch Gynecol Obstet. 2004;270:157-160.

31. Kadiiska MB, Gladen BC, Baird DD, et al. Biomarkers of oxidative stress study II. Are oxidation products of lipids, proteins, and DNA markers of $\mathrm{CCl} 4$ poisoning? Free Rad Biol Med. 2005;38:698-710 